\title{
Phenolic constituents and antioxidant properties of five wild species of Physalis (Solanaceae)
}

\author{
José Roberto Medina-Medrano, Norma Almaraz-Abarca*, M. Socorro González-Elizondo, \\ José Natividad Uribe-Soto, Laura Silvia González-Valdez and Yolanda Herrera-Arrieta
}

\begin{abstract}
Background: Fruits of wild species of the genus Physalis are consumed as food and calyces and leaves are used in traditional medicine. The phenolic composition of the species of this genus have been scarcely studied. To contribute to a better knowledge for the use of all the potential of these wild species of plants, leaves, fruits, and calyces of five wild species of the genus were analyzed for their phenolic composition and antioxidant properties.

Results: Important tissue- and species-dependent variations were found. Calyces of Physalis subulata showed the highest contents of phenolics (176.58 mg of gallic acid equivalents/g dry tissue), flavonoids (39.63 mg/g dry tissue), and phenolic acids (50.57 mg of quercitrin equivalents/g dry tissue), and its leaves displayed the highest total antioxidant capacity (3.59 mg of ascorbic acid equivalents $/ \mathrm{mL}$ ) and one of the highest reduction powers $(0.54 \mu \mathrm{g}$ of ascorbic acid equivalents $/ \mathrm{mL}$ ). A high performance liquid chromatography with photodiode array detection analysis revealed a total of 28 phenolic compounds in foliar tissues (mainly kaempferol-3-O-glycosides), 16 in fruits (mainly phenolic acids), and 16 in calyces (mainly kaempferol-3-O-glycosides); the profiles of these compounds in the three types of tissue were species-specific.

Conclusions: The studied species of Physalis are important sources of phenolics with relevant antioxidant activity. The current results indicate that phenolic profiles are valuable specific chemical markers and can be relevant as food tracing and authenticity indicators for plant-based preparations involving species of Physalis.
\end{abstract}

Keywords: Physalis, Antioxidant capacity, Phenolic profiles, Phenolic content

\section{Background}

Plants are a promising source of beneficial compounds for human health and represent a starting point for the discovery and development of drugs for the treatment of human diseases (Kouloura et al. 2014). There is an impressive plant diversity worldwide, in which the chemical variation is represented by a great deal of bioactive compounds. The interest in wild plants as a source of natural antioxidants is valid as a healthier and cheaper alternative to the synthetic ones, which have been perceived as toxic and carcinogenic (Krishnaiah et al. 2011).

\footnotetext{
*Correspondence: nalmaraz@ipn.mx; noralab@yahoo.com Centro Interdisciplinario de Investigación para el Desarrollo Integral Regional, Unidad Durango, Instituto Politécnico Nacional, Sigma 119, Fraccionamiento 20 de Noviembre II, 34220 Durango, Dgo., Mexico
}

The family Solanaceae is constituted by around 2300 species (D'Arcy 1991), which are significant sources of phytochemicals (Eick 2008). This family includes important cultivated species, such as chili (Capsicum annuum L.), tomato (Lycopersicon esculentum Mill.), and potato (Solanum tuberosum L.). The family also includes numerous wild species, like most belonging to the genus Physalis, which is the fifth largest genus of the family, including 70-90 species (Whitson and Manos 2005). Mexico, with about 50 species of Physalis growing in its territory, is considered the center of origin, diversity (D'Arcy 1991), and domestication of this genus (Santiaguillo et al. 1994). The fruits of many species of Physalis have been important elements in the culinary traditions of the people of Mesoamerica, consumed fresh or cooked, and calyces

\section{Springer}

(c) 2015 Medina-Medrano et al. This article is distributed under the terms of the Creative Commons Attribution 4.0 International License (http://creativecommons.org/licenses/by/4.0/), which permits unrestricted use, distribution, and reproduction in any medium, provided you give appropriate credit to the original author(s) and the source, provide a link to the Creative Commons license, and indicate if changes were made. 
and leaves have been used in folk medicine since preColumbian times. Calyces are also consumed as seasoning and leaves as food (Hernández and Yáñez 2009). However, at present, only a few species are cultivated, $P$. ixocarpa, P. peruviana, and $P$. alkekengi are among them.

Phenolic compounds are synthesized and accumulated in practically all plant tissues. Many of these compounds, mainly flavonoids and phenolic acids, have biological properties with medical implications (Zhang and Cui 2005). The antioxidant capacity is one of the most important of these properties, because oxidation damages nucleic acids, proteins, lipids, and other macromolecules, producing cardiovascular disorders, neurodegenerative diseases, and cancer (Ames et al. 1993). Flavonoids and phenolic acids have relevant antioxidant properties (Barriada-Bernal et al. 2014). The antioxidant capacity of plant phenolic extracts depends on their concentration (Dobre et al. 2010), but also on their accumulation profiles inside plant tissues (Barriada-Bernal et al. 2014). The concentration is affected by environmental conditions, age, and phenological stage (Almaraz-Abarca et al. 2013), while the qualitative phenolic profiles are more stable and vary among different groups of plants with a species-specific tendency (Emerenciano et al. 2001).

Few species of Physalis have been analyzed for their phenolic composition and antioxidant properties, among them are P. ixocarpa (González-Mendoza et al. 2011), $P$. peruviana (Rockenbach et al. 2008; Wu et al. 2009), $P$. angulata (Ismail and Alam 2001), and P. alkekengi var. franchetii (Diaz et al. 2012). The aim of the present study was to evaluate the abundance and diversity of phenolics and the antioxidant properties of leaves, edible fruits, and calyces of five wild species of Physalis [P. angulata L., P. patula Mill., P. hederifolia A. Gray var. hederifolia, P. solanacea (Schltdl.) Axelius, and P. subulata Rydb.] from Durango, Mexico to determine their potential as sources of natural antioxidants. The significance of the phenolic profiles as specific chemomarkers and their potential as tool for food tracing and authenticity was also evaluated.

\section{Methods}

\section{Plant material}

Leaves, fruits, and calyces of mature individuals (blooming and bearing fruits) of six natural populations of Physalis were collected in different locations of Durango, Mexico (Table 1). Tissues of four individuals per population were randomly sampled, combined, and three pools of samples were formed and separately analyzed. Voucher specimens were deposited at the Herbarium CIIDIR. Samples were individually dried in a ventilated oven at $40{ }^{\circ} \mathrm{C}$, and then ground in a domestic blender. The dry, ground tissues were kept in paper bags at room temperature, in a desiccator with silica, in darkness until analysis.

\section{Preparation of extracts}

Phenolic compounds were extracted from dry ground tissues $(1 \mathrm{~g})$ by maceration in $20 \mathrm{~mL}$ of $80 \%$ methanol (v/v), for $24 \mathrm{~h}$, by shaking at $100 \mathrm{rpm}$, in darkness, at room temperature. The extracts were centrifuged $(4800 g)$ for $5 \mathrm{~min}$ at room temperature and the supernatants formed the total extracts. Different aliquots were taken to be used in the determination of phenolic content, antioxidant potential, and HPLC-DAD analysis.

\section{Determination of total phenolics}

The concentrations of total phenolics of each sample were determined using the Folin-Ciocalteu reagent, according to Nurmi et al. (1996). The phenolic contents were calculated by using a calibration curve of gallic acid $\left(\mathrm{A}_{760}=0.003\right.$ [gallic acid] $\left.-0.0241, \mathrm{r}=0.9985\right)$ constructed with five concentrations of this compound $(0-92 \mu \mathrm{g} / \mathrm{mL})$. Phenolic contents were expressed as milligrams of gallic acid equivalents per gram of dry tissue (mg GAE/g dt).

\section{HPLC-DAD analysis}

The HPLC-DAD analysis was carried out according to Campos and Markham (2007). Aliquots $(20 \mu \mathrm{L})$ were analyzed in a Perkin Elmer Series 200 HPLC system and a Perkin Elmer Brownlee Analytical C18 column $(4.6 \times 250 \mathrm{~mm}, 5 \mu \mathrm{m})$, using an acidified

Table 1 Collection data for the Mexican studied species of Physalis

\begin{tabular}{|c|c|c|c|c|c|c|c|}
\hline Sample & $\begin{array}{l}\text { Curatorial } \\
\text { number }\end{array}$ & Species & Location & Latitude N & Longitude W & $\begin{array}{l}\text { Altitude } \\
\text { (m) }\end{array}$ & Date \\
\hline 401 & 42854 & P. angulata & Durango, Durango & $24^{\circ} 08^{\prime} 15.4^{\prime \prime}$ & $104^{\circ} 31^{\prime} 58.5^{\prime \prime}$ & 1864 & $8 / 08 / 2012$ \\
\hline 407 & 42861 & P. hederifolia var. hederifolia & Durango, Durango & $23^{\circ} 43^{\prime} 24.9^{\prime \prime}$ & $104^{\circ} 24^{\prime} 8.9^{\prime \prime}$ & 1975 & $21 / 08 / 2012$ \\
\hline 412 & 42866 & P. solanacea & Durango, Durango & $24^{\circ} 14^{\prime} 14.6^{\prime \prime}$ & $104^{\circ} 27^{\prime} 34^{\prime \prime}$ & 1872 & $4 / 09 / 2012$ \\
\hline 413 & 42867 & P.patula & Durango, Durango & $24^{\circ} 14^{\prime} 14.6^{\prime \prime}$ & $104^{\circ} 27^{\prime} 34^{\prime \prime}$ & 1872 & $4 / 09 / 2012$ \\
\hline 426 & 42882 & P. solanacea & Nombre de Dios, Durango & $23^{\circ} 58^{\prime} 19.3^{\prime \prime}$ & $104^{\circ} 19^{\prime} 28.2^{\prime \prime}$ & 1841 & $2 / 10 / 2012$ \\
\hline 427 & 42885 & P. subulata & Nombre de Dios, Durango & $23^{\circ} 47^{\prime} 50.6^{\prime \prime}$ & $103^{\circ} 51^{\prime} 9.44^{\prime \prime}$ & 2234 & $5 / 10 / 2012$ \\
\hline
\end{tabular}


acetonitrile-water gradient. Water adjusted to $\mathrm{pH} 2.5$ with orthophosphoric acid was solvent A, and acetonitrile was solvent $\mathrm{B}$, mixed following the gradient: starting with $100 \% \mathrm{~A}$, decreasing to $91 \%$ over the next $12 \mathrm{~min}$, to $87 \%$ over the next $8 \mathrm{~min}$, to $67 \%$ over the next $12 \mathrm{~min}$, to $57 \%$ over the next $10 \mathrm{~min}$, and held at this level until the end of the $60 \mathrm{~min}$ analysis. Chromatograms were plotted at 260 and $340 \mathrm{~nm}$. Spectral data for all peaks were accumulated in the range of $200-400 \mathrm{~nm}$ by using a diode array detection (Perkin Elmer Series 200). Structural information of compounds was obtained by direct comparisons of retention time (RT) and UV spectra of resolved compounds with those of standards caffeic acid (RT: 53.13, $\lambda_{\max }: 239 \mathrm{sh}, 295 \mathrm{sh}, 318$ ), $p$-coumaric acid (RT: 37.2, $\lambda_{\text {max }}: 293 \mathrm{sh}, 308$ ), quercetin (RT: 47.05, $\lambda_{\text {max }}: 255,268 \mathrm{sh}, 299 \mathrm{sh}, 370$ ), quercitrin (quercetin-3-Orhamnoside, RT: $\left.38.54, \lambda_{\max }: 255,264 \mathrm{sh}, 295 \mathrm{sh}, 348\right)$, morin (RT: 45.4, $\lambda_{\max }: 254,264 \mathrm{sh}, 298 \mathrm{sh}, 354$ ), hesperidin (RT: $39.34, \lambda_{\max }: 284,335 \mathrm{sh}$ ), and naringenin (RT: $\left.52.25, \lambda_{\max }: 289,335 \mathrm{sh}\right)$. Structural information was also obtained from the compilations of Mabry et al. (1970) and Campos and Markham (2007). The phenolic profile of each extract was formed by all compounds resolved in their respective chromatograms. Quantitative determinations were made by an external standard method, with the commercial references quercitrin (for flavonols), naringenin (for dihydroflavonoids), and $p$-coumaric acid (for phenolic acids), by area measurements, using standard curves (area $=3 \times 10^{6}+5 \times 10^{7}$ [quercitrin], correlation coefficient $\mathrm{r}=0.992$; area $=2 \times 10^{6}+5 \times 10^{7}$ [naringenin], correlation coefficient $r=0.996$; area $=3 \times 10^{6}+4 \times 10^{7}$ [ $p$-coumaric acid], correlation coefficient $r=0.999)$. The contents were expressed as micrograms of quercitrin equivalents, naringenin equivalents, or $p$-coumaric acid equivalents/g dry tissue (QiE/g dt, NE/g dt, and CE/g dt, respectively). The sum of individual flavonoid concentrations in one sample represented the total flavonoid concentration, expressed as milligram per gram of dry tissue $(\mathrm{mg} / \mathrm{g} \mathrm{dt})$, and the sum of individual phenolic acids corresponded to the total phenolic acid concentration, expressed as milligram per gram of dry tissue $(\mathrm{mg} / \mathrm{g} \mathrm{dt})$.

\section{Free radical scavenging activity}

Determination of the free radical scavenging activity was carried out following the $\mathrm{DPPH}^{*}$ method described by Barriada-Bernal et al. (2014). Decreases in absorbance (at $523 \mathrm{~nm})$ of an initial $\mathrm{DPPH}^{*}$ solution $(62 \mu \mathrm{g} / \mathrm{mL}$ methanol) against increasing flavonoid concentrations of samples were plotted to determine, by linear regression, the efficient concentration at $50 \%$, defined as the amount of antioxidant needed to decrease by $50 \%$ the initial $\mathrm{DPPH}^{*}$ concentration $\left(E_{50}\right)$. The following curve made with
$\mathrm{DPPH}^{*}$ between 2 and $60 \mu \mathrm{g} / \mathrm{mL}$ was used to estimate the $\mathrm{DPPH}^{*}$ concentration $(\mu \mathrm{g} / \mathrm{mL})$ in the reaction medium: $\mathrm{A}_{523 \mathrm{~nm}}=0.0019+0.0309\left[\mathrm{DPPH}^{*}\right]$, correlation coefficient $\mathrm{r}=0.9996$. Antiradical activities were expressed in terms of $\mathrm{EC}_{50}$ in microgram per milliliter $(\mu \mathrm{g} / \mathrm{mL})$. Quercetin and epicatechin were analyzed in the same manner as references.

\section{Total antioxidant capacity (TAC)}

Total antioxidant capacity was evaluated according to Prieto et al. (1999). In this method, the reduction of Mo (VI) to Mo (V) by an antioxidant, forming a green phosphate/Mo (V) complex at an acidic $\mathrm{pH}$ is measured. TAC values were expressed as milligrams of ascorbic acid equivalents $/ \mathrm{mL}(\mathrm{AAE} / \mathrm{mL})$, which were calculated using the following curve: $\mathrm{A}_{695}=-0.2365+4.2133$ [ascorbic acid], correlation coefficient $r=0.9987$, constructed with six concentrations of ascorbic acid between 0.1 and $1 \mathrm{mg} /$ $\mathrm{mL}$. Quercetin $(0.1 \mathrm{mg} / \mathrm{mL})$ and epicatechin $(0.1 \mathrm{mg} / \mathrm{mL})$ were analyzed in the same manner as references.

\section{Iron reducing power}

The iron reducing power method is based on the measurement of the formation of $\mathrm{Fe}^{2+}$ from $\mathrm{Fe}^{3+}$ in the presence of antioxidants; $\mathrm{Fe}^{2+}$ was estimated according to Siddhuraju and Becker (2003). Results were expressed in terms of $\mathrm{IC}_{50}$ in micrograms of ascorbic acid equivalents per milliliter $(\mu \mathrm{gAE} / \mathrm{mL})$, calculated from the following curve of ascorbic acid: $\mathrm{A}_{700}=25.372$ [ascorbic acid] -0.0242 , correlation coefficient $r=0.9956$, constructed with five concentrations of ascorbic acid between 0.03 and $0.1 \mathrm{mg} / \mathrm{mL}$. The highest absorbance values indicated the greatest reducing capacity. Quercetin and epicatechin were analyzed in the same manner as references.

\section{Data analysis}

All the assays were carried out for three independent pools of each sample. Data were subjected to an analysis of variance ( $\mathrm{p} \leq 0.05)$, and means were separated by Tukey test. Correlations between different parameters were carried out with Pearson test, by using the SPSS statistics 17.0 software. A principal component analysis (PCA), considering all the quantitative parameters, was carried out by using Past 3.0; the contribution of each parameter for the differentiation of samples was evaluated. For the different tissues (leaves, fruits, and calyces), the phenolic profiles were made up of all compounds present in the respective HPLC-DAD chromatogram. Each compound was treated as a single chemical character. A binary matrix coded by 1 (presence) or 0 (absence) formed by all individual samples vs. all resolved compounds for each type of tissue was subjected to a cluster 
analysis (paired group algorithm and Jaccard similarity measure) by using Past 3.0.

\section{Results}

\section{Phenolic, flavonoid and phenolic acid contents}

The phenolic contents are displayed in Table 2. Significant tissue and species-dependent variations were found. Among the foliar tissues, the leaves of $P$. patula accumulated the highest level of phenolics $(129 \mathrm{mg} / \mathrm{g} \mathrm{dt})$ and among the fruits, those of $P$. hederifolia var. hederifolia were the richest ones in total phenolics $(86.51 \mathrm{mg} / \mathrm{g} \mathrm{dt})$. The calyx phenolic content of $P$. subulata was the highest found in the current study $(176.58 \mathrm{mg} / \mathrm{g} \mathrm{dt})$.

Table 2 shows the flavonoid contents found in the different tissues of the analyzed species of Physalis. Significant tissue and species-dependent variations were found. The foliar flavonoid contents explained between 7.55 and $56.86 \%$ of total phenolics, the highest level was found for P. angulata $(23.036 \mathrm{mg} / \mathrm{g} \mathrm{dt})$. Flavonoid contents in fruits represented between 0.0 and $16.91 \%$ of total phenolics, the fruits of $P$. subulata showed the highest level $(5.462 \mathrm{mg} / \mathrm{g}$ $\mathrm{dt}$ ). Flavonoid levels in calyces (representing between 3.08 and $30.43 \%$ of total phenolics) ranged from $3.67 \mathrm{mg} / \mathrm{g} \mathrm{dt}$ in $P$. solanacea (sample 412) to $39.63 \mathrm{mg} / \mathrm{g} \mathrm{dt}$ in P. subulata.

Species- and tissue-dependent variations were also found in the phenolic acid contents (Table 2). In leaves, phenolic acids corresponded to between 2.11 and $16.55 \%$ of total phenolics and P. angulata leaves showed the highest level ( $6.7 \mathrm{mg} / \mathrm{g}$ dry tissue). In fruits, phenolic acids represented between 0.0 and $21.25 \%$ of total phenolics; the fruits of Physalis angulata were the richest in these type of phenolics $(7.84 \mathrm{mg} / \mathrm{g} \mathrm{dt})$. Excepting the calyces of $P$. hederifolia var. hederifolia, which practically did not accumulate phenolic acids, these compounds explained from between 2.86 and $28.63 \%$ of total phenolics. The content of phenolic acids in the calyces of $P$. subulata $(50.57 \mathrm{mg} / \mathrm{g} \mathrm{dt})$ was outstanding.

\section{Phenolic profiles}

Compounds 22 ( $\lambda_{\max }: 255,264$ sh, 294sh, 355), F7 ( $\lambda_{\max }$ : 255, 264sh, 294sh, 355), and C11 ( $\lambda_{\max }: 255,264 \mathrm{sh}$, 294sh, 355) were proposed as rutin because of its spectral data corresponded to those reported by Campos and Markham (2007) for that flavonol ( $\lambda_{\max }: 255,264$ sh, 294sh, 355).

The HPLC-DAD analysis revealed a total of 28 phenolic compounds in the leaves of the five species of Physalis analyzed (the respective chromatograms are shown in Fig. 1). Twenty of those compounds were flavonols (among them, 14 were kaempferol-3-O-glycosides and 5 were quercetin-3-O-glycosides) and 8 were phenolic acids. The respective retention times and $\lambda_{\max }$ are displayed in Table 3. The HPLC chromatograms of fruits (Fig. 2) revealed a total of 16 compounds: 11 phenolic acids, 3 flavonols (2 quercetin-3-O-glycosides and 1 kaempferol-3-O-glycoside), and 2 dihydroflavonols (retention times and $\lambda_{\max }$ are displayed in Table 3). A total of 16 phenolic compounds were unveiled by the chromatograms of calyces (Fig. 3), among which 12 were flavonols (10 kaempferol-3-O-glycosides and 2 quercetin-3-O-glycosides) and 4 were phenolic acids (Table 3 ). The concentration of each phenolic compound found in the different analyzed species is shown in Table 3.

\section{Cluster analysis}

The results of the cluster analysis based on the matrices constructed with each foliar, fruit, and calyx phenolic profile of each sample of Physalis are displayed in Fig. 4. All species were discriminated one from each other at levels of similarity from around 0.06 (Jaccard similarity measure, according to the foliar phenolic profiles) to around 0.42 (according to the calyx phenolic profiles).

\section{Antioxidant assays}

The results of the free radical scavenging activity, total antioxidant capacity, and iron reducing power are shown in Table 2. Specific and tissue dependent variations were found in the three antioxidant assays.

\section{Correlation analysis}

While the kinetic evaluation of all the antioxidant assays was highly related to flavonoid contents $(0.9731<\mathrm{r}<0.999)$, the correlation analysis revealed lower associations between the antioxidant properties and the phenolic, flavonoid, and phenolic acid contents in the samples ( 0.224 between calyx total flavonoids and calyx $\mathrm{IC}_{50}<$ Pearson correlation value $<0.856$ between calyx total phenolics and calyx $\mathrm{IC}_{50}$ ).

\section{Principal component analysis}

The results of a PCA, based on the quantitative determinations (phenolic, flavonoid, and phenolic acid contents and the estimation of antioxidant capacity by three methods) are showed in the Fig. 5. Three principal components accounted for $93.77 \%$ of total variance, being the calyx phenolic content (PC1) the main one, taking $73.467 \%$, with the highest relative discriminating power (eigenvalue 4860.76). The calyx antiradical activity (PC2) explained the $12.425 \%$ of total variance (eigenvalue $822.079)$, and the foliar phenolic content, the $7.88 \%$ (eigenvalue 521.505).

\section{Discussion}

\section{Phenolic, flavonoid, and phenolic acid contents}

Phenolic compounds contribute to the organoleptic and antioxidant properties of foods and they are among 


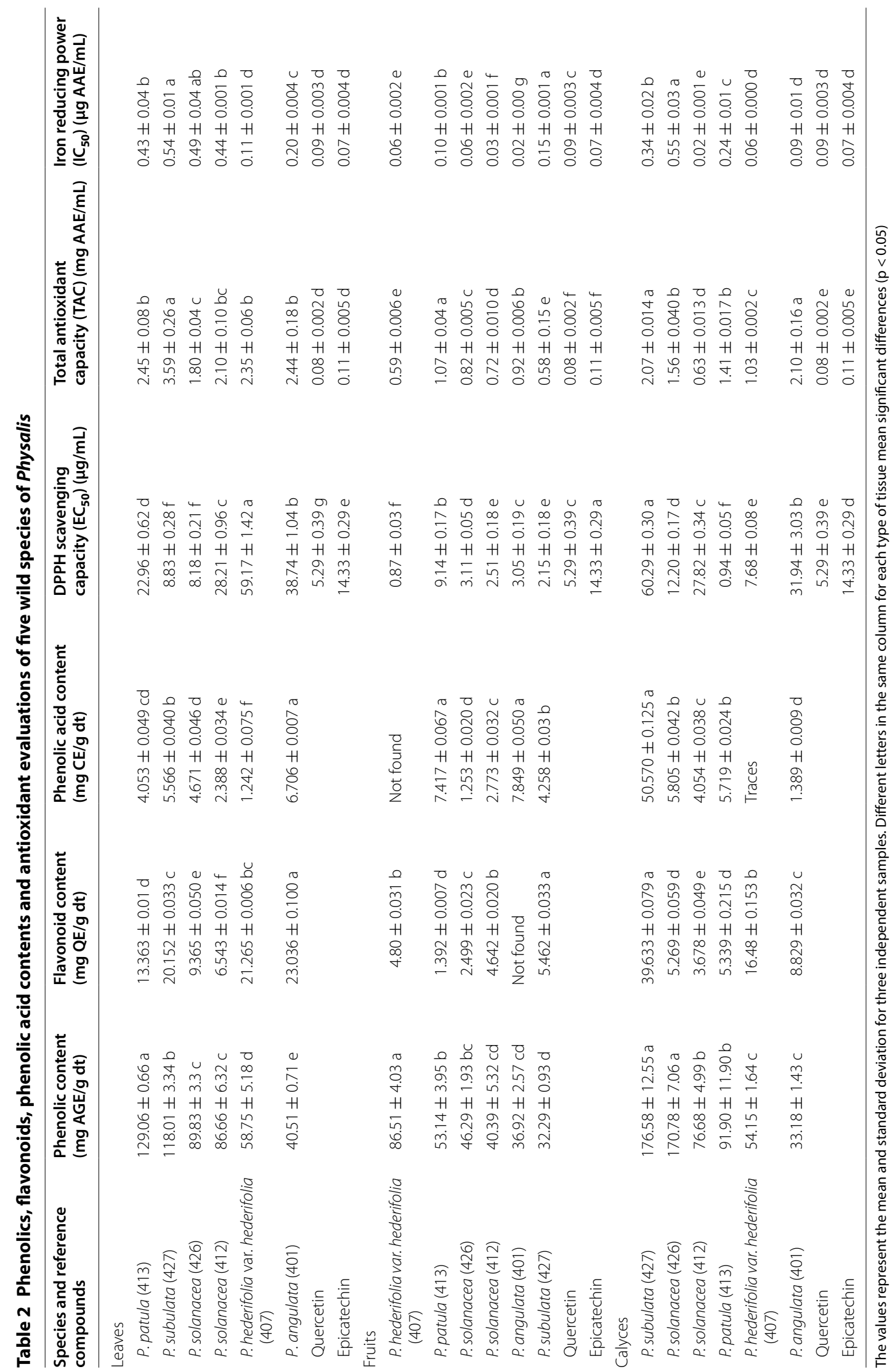



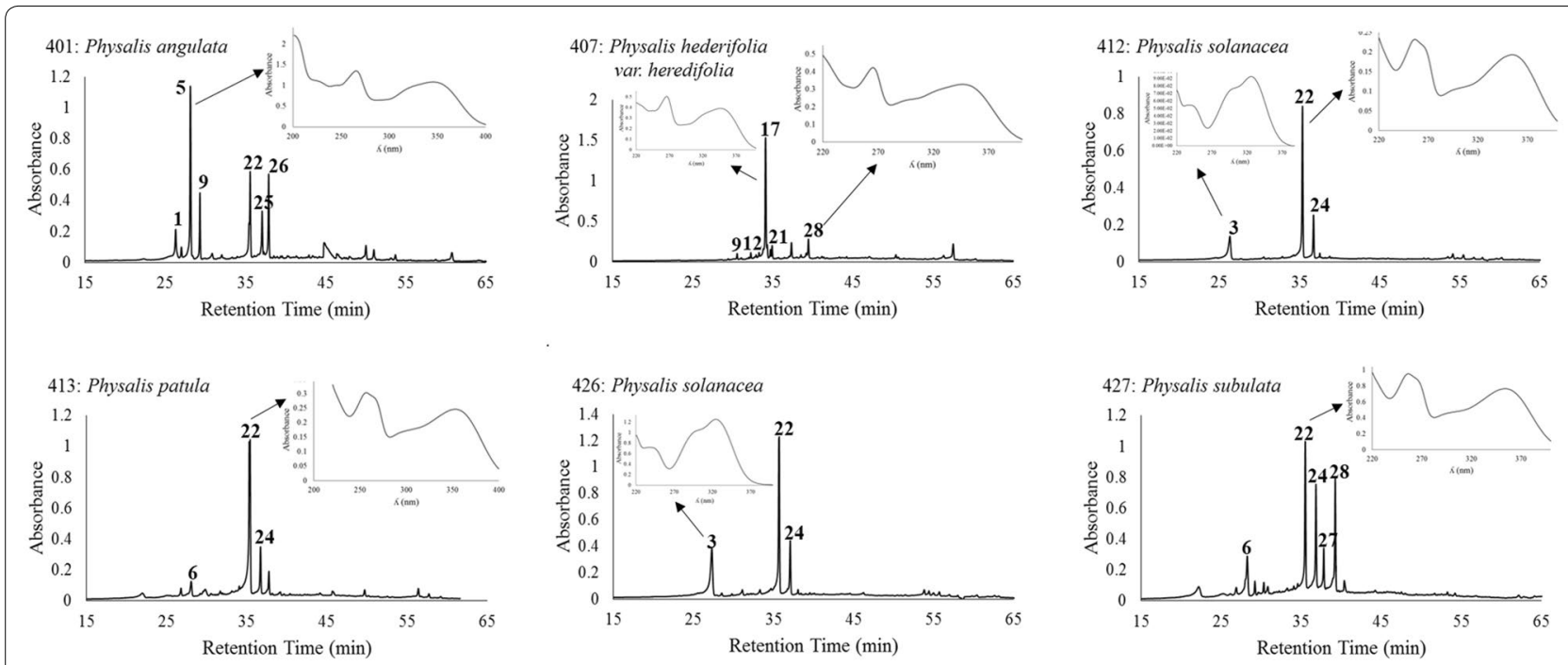

Fig. 1 HPLC chromatograms and UV spectra of the major foliar phenolics of five species of Physalis. The HPLC chromatograms were registered at $260 \mathrm{~nm}$ and the UV spectra of the resolved compounds were obtained from 200 to $400 \mathrm{~nm}$. The number of compounds corresponds to those of Table 3

the most important nutraceuticals of interest in food industry (Tapas et al. 2008). Some, like phenolic acids, play important roles in fruit maturation, prevention of enzymatic browning, and food preservation (Robbins 2003). Phenolics also represent important tools for food tracing and to prove authenticity of foods (Zimmermann and Galensa 2007). The understanding of their abundance, diversity, and distribution in the plant kingdom and in the different plant tissues offers the opportunity of developing new drugs to improve human health, and to develop new varieties with enhanced accumulation of these compounds through breeding programs.

The potential of different species to synthesize and accumulate flavonoids, and phenolics in general, is the result of the interaction of genetic and environmental factors (Veit et al. 1995) and different species of plants can synthesize and accumulate widely variable levels (Diaz et al. 2012). Aside from the differences in the flavonoid levels due to diverse environmental conditions of growing and to the specific variations, differences between tissues can be expected as the result of the differential regulation of the genic expression in well differentiated cells.

The total phenolic concentrations observed in the leaves and fruits of the analyzed species of Physalis were comparable to those reported by Wang and Lin (2000) in the leaves (30.9-129.2 mg/g dry matter) and fruits (9.16$23.10 \mathrm{mg} / \mathrm{g}$ dry matter basis) of several cultivars of black raspberry, red raspberry, and strawberries, all considered as important source of phenolics. To our knowledge, this is the first report of phenolic contents in calyx for the species here analyzed of Physalis and reveals that these structures can accumulate relevant phenolic levels. The present results indicate that the species analyzed of Physalis are important sources of total phenolics, mainly accumulated in leaves and calyces.

Comparatively, the found foliar flavonoid contents were lower than those reported by Wu et al. (2009) for the leaves of P. peruviana (37.39-226.19 mg/g dry extract, depending on the type of solvent used for the extraction). Excepting P. angulata, in whose fruits no flavonoids were found, the fruit flavonoid contents found in the present study (Table 2) were higher than that reported for ripe fruits of Lycium barbarum (Fructus Lycii) ( $0.72 \mathrm{mg} / \mathrm{g}$ dry fruit), whose importance as source of antioxidants has been reported by Le et al. (2007). The flavonoid levels found in the calyces of P. subulata (Table 2) can be comparable to that reported for the aqueous extract of $P$. peruviana leaves $(37.39 \mathrm{mg} / \mathrm{g})$ by Wu et al. (2009). Flavonoids were mainly accumulated in leaves and calyces.

Studies on determinations of phenolic acids in species of Physalis have been mainly focused on fruits (Rockenbach et al. 2008); however, the current results reveal that leaves and calyces of the species of Physalis can accumulate these phenolics at similar or even higher levels than fruits (Table 2).

\section{Phenolic profiles}

Quercetin derivatives, kaempferol derivatives, and phenolic acids were the major phenolic compounds 
Table 3 Phenolic compounds found in the leaves, fruits, and calyces of five wild species of Physalis

\begin{tabular}{|c|c|c|c|c|}
\hline $\begin{array}{l}\text { Number of } \\
\text { compound }\end{array}$ & RT (min) & $\lambda_{\max }$ & $\begin{array}{l}\text { Type of phenolic } \\
\text { compound }\end{array}$ & Species \\
\hline \multicolumn{5}{|l|}{ Leaves } \\
\hline 1 & $26.50 \pm 0.11$ & $256,267 s h, 319,360$ sh & Flavonol & P. angulata (2.476) \\
\hline 2 & $22.57 \pm 0.36$ & 240sh, 296sh, 326 & Phenolic acid & P. subulata (2.184) \\
\hline 3 & $27.37 \pm 0.07$ & 240sh, 296sh, 325 & Phenolic acid & P. solanacea (412: 2.288; 426: 4.671) \\
\hline 4 & $27.23 \pm 0.11$ & $256,266 s h, 347$ & Quercetin-3-O-glycoside & P. angulata (1.544) \\
\hline 5 & $28.41 \pm 0.02$ & $243 s h, 265,317 s h, 345$ & Kaempferol-3-O-glycoside & P. angulata (5.094) \\
\hline 6 & $28.36 \pm 0.32$ & 233sh, 291sh, 324 & Phenolic acid & $\begin{array}{l}\text { P. angulata (1.281) } \\
\text { P. patula (2.467) } \\
\text { P. hederifolia var hederifolia (1.242) } \\
\text { P. subulata (3.381) }\end{array}$ \\
\hline 7 & $28.73 \pm 0.05$ & $227 s h, 243 s h, 265,344$ & Kaempferol-3-O-glycoside & P. subulata (1.522) \\
\hline 8 & $29.63 \pm 0.24$ & 243sh, 290sh, 322 & Phenolic acid & P.patula (1.586) \\
\hline 9 & $29.65 \pm 0.09$ & $227 s h, 265,343$ & Kaempferol-3-O-glycoside & $\begin{array}{l}\text { P.angulata (2.329) } \\
\text { P. hederifolia var. hederifolia (1.412) } \\
\text { P. subulata (1.524) }\end{array}$ \\
\hline 10 & $31.17 \pm 0.07$ & 229sh, 268sh, 308 & Phenolic acid & P. angulata (1.417) \\
\hline 11 & $31.87 \pm 0.00$ & 231sh, 267sh, 312 & Phenolic acid & P. angulata (1.268) \\
\hline 12 & $32.21 \pm 0.05$ & $256,266 s h, 353$ & Quercetin-3-O-glycoside & P. hederifolia var. hederifolia (1.403) \\
\hline 13 & $32.43 \pm 0.03$ & 226sh, 295sh, 312 & $\begin{array}{l}\text { Phenolic acid (probably p-coumaric } \\
\text { acid) }\end{array}$ & P. angulata (1.341) \\
\hline 14 & $32.93 \pm 0.00$ & 265,318 sh, 354 & Kaempferol-3-O-glycoside & P. hederifolia var. hederifolia (1.331) \\
\hline 15 & $33.29 \pm 0.00$ & 228sh, 266, 320sh, 343 & Kaempferol-3-O-glycoside & P. hederifolia var. hederifolia (1.515) \\
\hline 16 & $33.82 \pm 0.00$ & 228sh, 265, 317sh, 345 & Kaempferol-3-O-glycoside & P. hederifolia var. hederifolia (1.897) \\
\hline 17 & $34.16 \pm 0.00$ & 227sh, 244sh, 265, 318sh, 345 & Kaempferol-3-O-glycoside & P. hederifolia var. hederifolia (6.868) \\
\hline 18 & $34.29 \pm 0.00$ & 228sh, 265, 317sh, 346 & Kaempferol-3-O-glycoside & P. hederifolia var. hederifolia (1.538) \\
\hline 19 & $34.58 \pm 0.00$ & 236sh, 270sh, 290sh, 324 & Phenolic acid & P. angulata (1.397) \\
\hline 20 & $34.75 \pm 0.10$ & 265,294 sh, 344 & Kaempferol-3-O-glycoside & P. hederifolia var. hederifolia (1.583) \\
\hline 21 & $34.90 \pm 0.03$ & 228sh, 245sh, 266, 345 & Kaempferol-3-O-glycoside & P. hederifolia var. hederifolia (1.631) \\
\hline 22 & $35.69 \pm 0.20$ & 255, 264sh, 294sh, 355 & Quercetin-3-O-glycoside (rutine) & $\begin{array}{l}\text { P. angulata }(5.175) \\
\text { P. patula }(5.431) \\
\text { P. solanacea }(412: 4.388 ; 426: 6.882) \\
\text { P. subulata }(5.892)\end{array}$ \\
\hline 23 & $34.85 \pm 0.60$ & 255,266sh, 296sh, 355 & Quercetin-3-O-glycoside & P. patula $(3.627)$ \\
\hline 24 & $36.24 \pm 0.34$ & 256, 266sh, 296sh, 353 & Quercetin-3-O-glycoside & $\begin{array}{l}\text { P. patula (2.421) } \\
\text { P. solanaceous (412: 2.154, 426: 4.682) } \\
\text { P. subulata (4.599) }\end{array}$ \\
\hline 25 & $36.47 \pm 0.16$ & 227sh, 265, 294sh, 346 & Kaempferol-3-O-glycoside & P. angulata (2.837) \\
\hline 26 & $37.40 \pm 0.22$ & 227sh, 265, 294sh, 346 & Kaempferol-3-O-glycoside & $\begin{array}{l}\text { P. angulata }(3.577) \\
\text { P.patula }(1.879)\end{array}$ \\
\hline 27 & $38.20 \pm 0.08$ & 265, 293sh, 343 & Kaempferol-3-O-glycoside & P. subulata $(2.597)$ \\
\hline 28 & $39.44 \pm 0.12$ & 264, 293sh, 346 & Kaempferol-3-O-glycoside & $\begin{array}{l}\text { P. hederifolia var. hederifolia (2.032) } \\
\text { P. subulata (3.977) }\end{array}$ \\
\hline \multicolumn{5}{|l|}{ Fruits } \\
\hline $\mathbf{F 1}$ & $26.648 \pm 0.489$ & 293sh, 325 & Phenolic acid & $\begin{array}{l}\text { Physalis solanacea (412: } 2.773 ; 426 \text { : } \\
\quad 1.253) \\
\text { P. subulata }(2.470)\end{array}$ \\
\hline $\mathbf{F 2}$ & $27.389 \pm 0.187$ & 296sh, 322 & Phenolic acid & $\begin{array}{l}\text { P. angulata }(1.534) \\
\text { P. patula }(1.144) \\
\text { P. subulata }(1.787)\end{array}$ \\
\hline F3 & $29.821 \pm 0.000$ & 292sh, 326 & Phenolic acid & P. angulata (1.536) \\
\hline F4 & $30.716 \pm 0.000$ & 283sh, 311 & Phenolic acid & P.patula $(1.163)$ \\
\hline F5 & $33.488 \pm 0.000$ & $226 s h, 265,346$ & Kaempferol-3-O-glycoside & P. hederefolia var hederifolia (4.807) \\
\hline F6 & $34.47 \pm 0.000$ & 291sh, 311 & Phenolic acid & P.patula (1.232) \\
\hline
\end{tabular}


Table 3 continued

\begin{tabular}{|c|c|c|c|c|}
\hline $\begin{array}{l}\text { Number of } \\
\text { compound }\end{array}$ & $\mathrm{RT}$ (min) & $\lambda_{\max }$ & $\begin{array}{l}\text { Type of phenolic } \\
\text { compound }\end{array}$ & Species \\
\hline F7 & $35.138 \pm 0.323$ & 255, 264sh, 294sh, 355 & Quercetin-3-O-glycoside & $\begin{array}{l}\text { P. patula (1.392) } \\
\text { P. solanacea }(412: 2.320,426: 1.282) \\
\text { P. subulata (1.765) }\end{array}$ \\
\hline $\mathbf{F 8}$ & $37.55 \pm 0.000$ & $281,324 s h$ & Dihydroflavonol & P. subulata (1.765) \\
\hline F9 & $39.193 \pm 0.000$ & $277,303 s h$ & Dihydroflavonol & P. subulata (1.932) \\
\hline F10 & $45.69 \pm 0.000$ & 286sh, 312 & Phenolic acid & P.patula (1.134) \\
\hline F11 & $45.954 \pm 0.000$ & 283sh, 317 & Phenolic acid & P. angulata (1.593) \\
\hline F12 & $46.937 \pm 0.000$ & 291sh, 311 & Phenolic acid & P.patula (1.282) \\
\hline F13 & $50.091 \pm 0.397$ & $255,267 s h, 296 s h, 355$ & Quercetin-3-O-glycoside & P. solanaceous (412: 2.322; 426: 1.217) \\
\hline F14 & $52.628 \pm 0.000$ & 292sh, 321 & Phenolic acid & P. angulata $(1.610)$ \\
\hline F15 & $55.928 \pm 0.000$ & 290sh, 312 & Phenolic acid & P.patula (1.429) \\
\hline F16 & $57.497 \pm 0.000$ & 281sh, 318 & Phenolic acid & P. angulata (1.573) \\
\hline \multicolumn{5}{|l|}{ Calyces } \\
\hline C1 & $23.055 \pm 0.054$ & 246sh, 290sh, 322 & Phenolic acid & $\begin{array}{l}\text { Physalis angulata (1.389) } \\
\text { Physalis subulata (25.085) }\end{array}$ \\
\hline $\mathrm{C2}$ & $27.855 \pm 0.287$ & $246 s h, 292,326$ & Phenolic acid & $\begin{array}{l}\text { Physalis solanacea (412: } 2.034 ; 426 \text { : } \\
\quad 3.100) \\
\text { P. patula (3.085) } \\
\text { Physalis subulata (12.132) }\end{array}$ \\
\hline C3 & $28.574 \pm 0.000$ & 226sh, 266, 287sh, 347 & Kaempferol-3-O-glycoside & Physalis angulata (1.549) \\
\hline C4 & $29.180 \pm 0.040$ & 242sh, 286sh, 322 & Phenolic acid & $\begin{array}{l}\text { Physalis patula (2.634) } \\
\text { Physalis subulata (13.352) }\end{array}$ \\
\hline C5 & $29.641 \pm 0.000$ & 228 sh, 265,345 & Kaempferol-3-O-glycoside & Physalis angulata (1.558) \\
\hline C6 & $31.400 \pm 0.317$ & 246sh, 316 & Phenolic acid & $\begin{array}{l}\text { Physalis solanacea (412: 2.020; } 426 \text { : } \\
2.704)\end{array}$ \\
\hline C7 & $33.172 \pm 0.036$ & 229sh, 266, 318sh, 344 & Kaempferol-3-O-glycoside & $\begin{array}{l}\text { Physalis hederifolia var. hederifolia } \\
\text { (3.084) }\end{array}$ \\
\hline C8 & $33.572 \pm 0.146$ & 227sh, 2656, 316sh, 346 & Kaempferol-3-O-glycoside & $\begin{array}{l}\text { Physalis hederifolia var. hederifolia } \\
(4.214)\end{array}$ \\
\hline $\mathrm{C9}$ & $33.605 \pm 0.000$ & 229sh, 266, 319sh, 344 & Kaempferol-3-O-glycoside & $\begin{array}{l}\text { Physalis hederifolia var. hederifolia } \\
\text { (3.023) }\end{array}$ \\
\hline C10 & $34.016 \pm 0.000$ & $225 s h, 265,340$ & Kaempferol-3-O-glycoside & $\begin{array}{l}\text { Physalis hederifolia var. hederifolia } \\
\text { (3.017) }\end{array}$ \\
\hline C11 & $35.990 \pm 0.064$ & 255, 264sh, 294sh, 355 & Quercetin-3-O-glycoside, (Rutin) & $\begin{array}{l}\text { Physalis angulata (2.087) } \\
\text { Physalis solanacea }(412: 2.032 ; 426 \text { : } \\
\text { 2.671) } \\
\text { Physalis patula (3.080) } \\
\text { Physalis subulata (13.885) }\end{array}$ \\
\hline C12 & $37.407 \pm 0.135$ & 267sh, 265, 293sh, 340 & Kaempferol-3-O-glycoside & $\begin{array}{l}\text { Physalis angulata (1.320) } \\
\text { Physalis patula (2.124) }\end{array}$ \\
\hline C13 & $37.55 \pm 0.000$ & $256,266 s h, 295,352$ & Quercetin-3-O-glycoside & Physalis subulata (13.278) \\
\hline C14 & $38.606 \pm 0.000$ & $265,293 s h, 346$ & Kaempferol-3-O-glycoside & $\begin{array}{l}\text { Physalis solanaceous (412: 1.646; } 426 \text { : } \\
\text { 2.631) }\end{array}$ \\
\hline C15 & $38.437 \pm 0.175$ & 225sh, 265, 291sh, 346 & Kaempferol-3-O-glycoside & $\begin{array}{l}\text { Physalis angulata (2.335) } \\
\text { Physalis hederifolia var. hederifolia } \\
(3.146)\end{array}$ \\
\hline C16 & $39.897 \pm 0.000$ & $226 s h, 265,345$ & Kaempferol-3-O-glycoside & Physalis subulata (12.469) \\
\hline
\end{tabular}

Figures in brackets mean concentration ( $\mathrm{mg} / \mathrm{g}$ dry tissue)

synthesized by the five species analyzed of Physalis, and were accumulated with a species-specific tendency.

The leaves of $P$. angulata accumulated the highest number of phenolics (12 compounds) and those of P. solanacea the lowest (3 compounds) (Table 3). Rutin (compound 22) was found in all species (as one of the dominant compounds), except in $P$. hederifolia var. hederifolia, whose leaves were rich in 

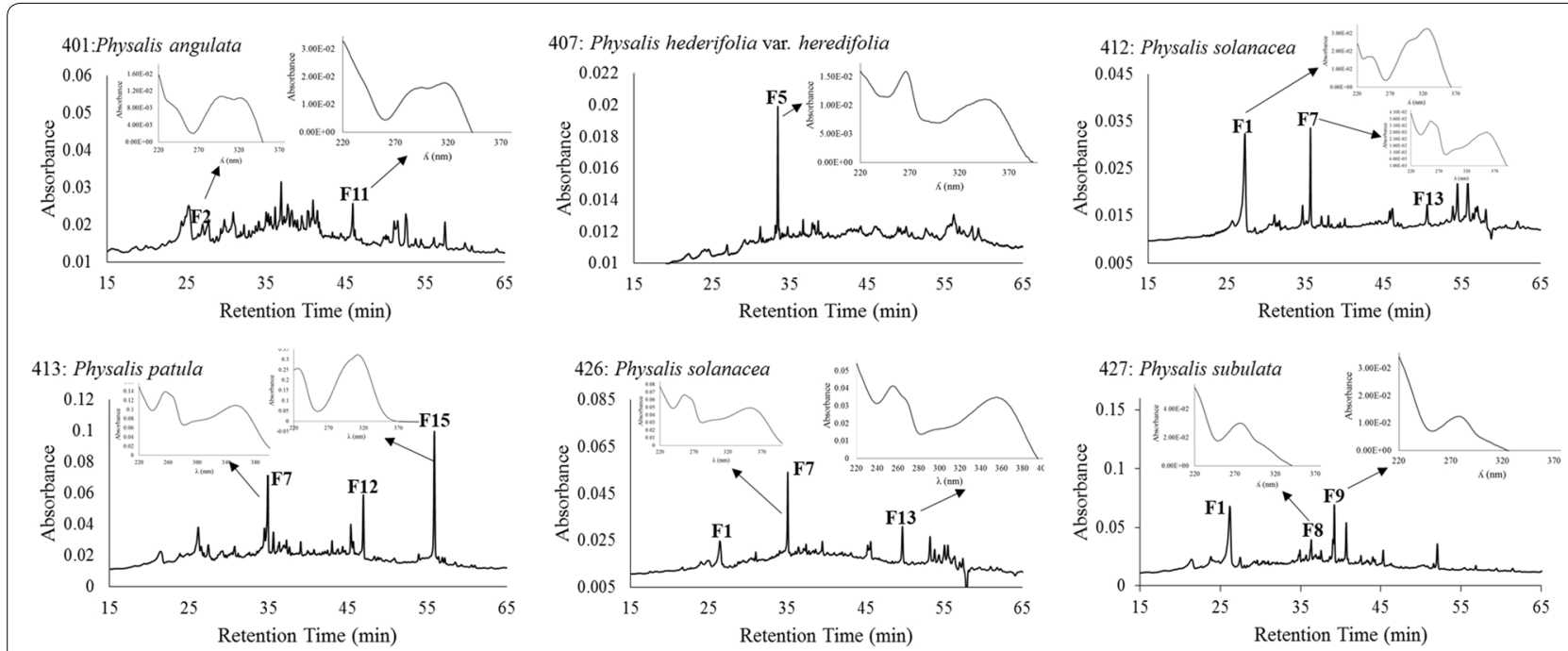

Fig. 2 HPLC chromatograms and UV spectra of major fruit phenolics of five species of Physalis. The HPLC chromatograms were registered at $260 \mathrm{~nm}$ and the UV spectra of the resolved compounds were obtained from 200 to $400 \mathrm{~nm}$. The number of compounds corresponds to those of Table 3
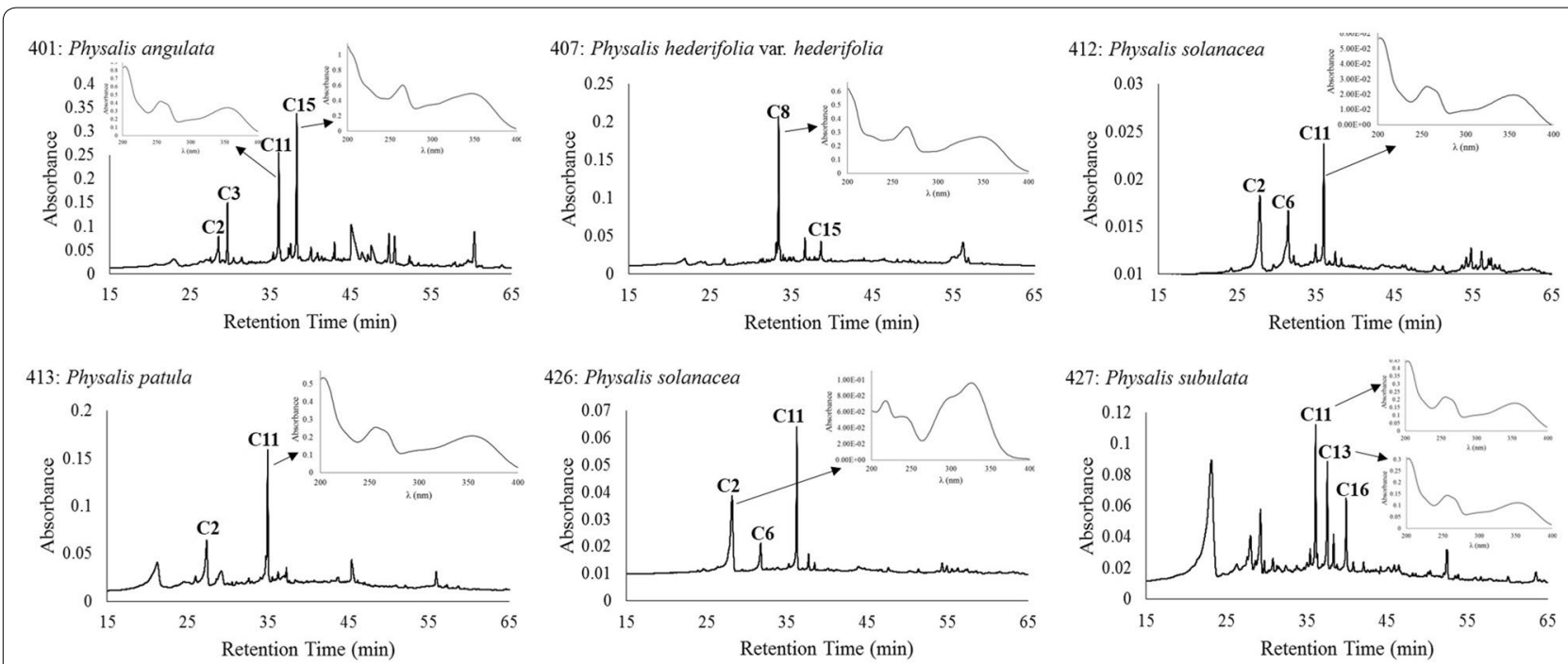

Fig. 3 HPLC chromatograms and UV spectra of major calyx phenolics of five species of Physalis. The HPLC chromatograms were registered at $260 \mathrm{~nm}$ and the UV spectra of the resolved compounds were obtained from 200 to $400 \mathrm{~nm}$. The number of compounds corresponds to those of Table 3

kaempferol-3-O-glycosides (9 among 11 compounds were kaempferol derivatives). Rutin has also been reported in aerial parts of Physalis orizabae (Maldonado et al. (2012). Myricetin-3-O-neohesperidoside ( $\lambda_{\max }: 266$, 299sh, 356) was reported in methanol extracts of leaves of $P$. angulata by Ismail and Alam (2001); however, the current results revealed no myricetin derivatives for any of the analyzed species.

In fruits, phenolic acids were the dominant compounds (Table 3), except for $P$. hederifolia var. hederifolia.
A similar dominance has been reported for the fruits of P. peruviana (Rockenbach et al. 2008). Relevant interspecific differences were observed in the phenolic composition, for example, for the fruits of $P$. hederifolia var. hederifolia the only phenolic compound found was one kaempferol-3-O-glycoside (F5) (Fig. 2), this contrasts with the composition found for the other four species and with the results reported for P. peruviana (Rockenbach et al. 2008). Rutin and myricetin have been found in the fruits of $P$. peruviana, rutin being present as a 


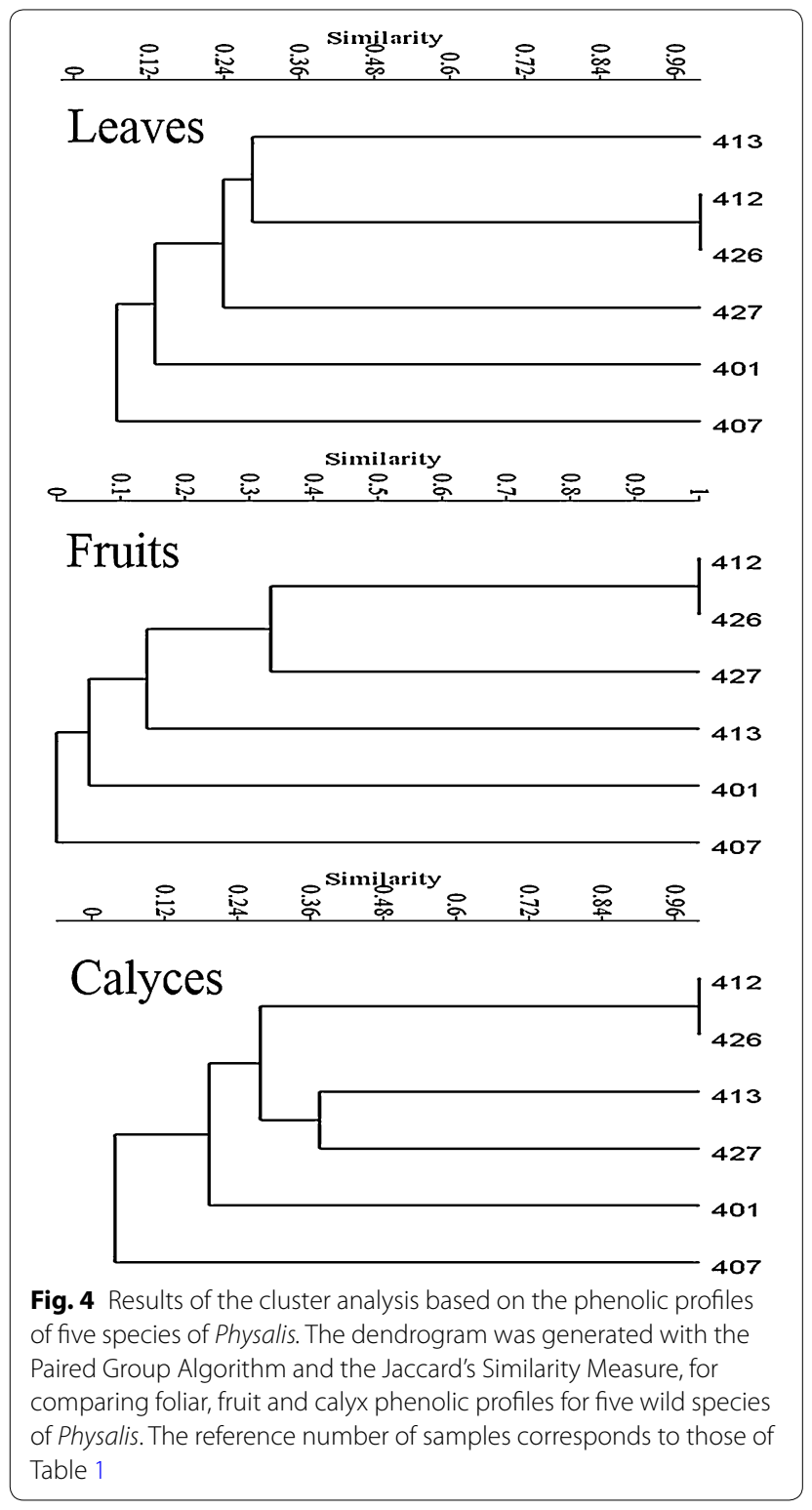

predominant compound (Licodiedoff et al. 2013). Rutin (compound F7) was also present in the fruits of $P$. patula, $P$. solanacea, and P. subulata, and in the two first species it was one of the dominant compounds (Fig. 2). However, none of the spectral data found in the present study corresponded to those of myricetin reported by Campos and Markham (2007) ( $\lambda_{\max }: 252,263 s h, 298$ sh, 371 ) or by Mabry et al. (1970) ( $\lambda_{\max }: 254,272$ sh, 301sh, 374). The fruits of P. subulata contained dihydroflavonoids (F8 and F9), which are less common phenolics in plant kingdom than flavonoids. The concentrations of F8 and F9 were similar to those of most phenolic acids (Table 3). Dihydroflavonoids can be important inhibitors of tumor development, antioxidant, and analgesic (Wong and Rabie 2009). The fruits of $P$. patula accumulated the highest number of phenolic compounds (seven).

In calyces of $P$. hederifolia var. hederifolia, as in its leaves and fruits, the dominant compounds were kaempferol-3-O-glycosides, and this was the only species in whose calyces, rutin (compound C11) was missing. Rutin has also been reported in the calyx of $P$. solanacea by Pérez-Castorena et al. (2013). The number of compounds accumulated in the calyces varied from 4 in P. solanacea and P. patula to 7 in P. subulata.

The concentrations of the individual phenolics were variable between species and between tissues. The highest level was found for compound C1, a phenolic acid accumulated in the calyces of $P$. subulata (Table 3). Comparatively, the individual phenolic acid concentrations of fruits and calyces were higher than the concentrations reported by Rockenbach et al. (2008) for the fruits of Physalis peruviana.

\section{Cluster analysis}

The results of the cluster analysis suggests that the phenolic profiles obtained by HPLC-DAD (Fig. 4) were species-specific, independent from location and time of collection, as indicated for the two samples of $P$. solanacea (Jaccard similarity value of 1 ), in such a way that each species can be typified by its phenolic profile. These phenol profiles can be important specific chemotaxonomic markers for Physalis and may contribute to solve taxonomic controversies around the delimitation of species mentioned by several authors (Whitson and Manos 2005). The species-specific feature of the profiles can be used also as a tool to typify, trace, and define the authenticity of fruits and preparations of these species. The chemical diversity revealed for the five wild analyzed species of Physalis can be a starting point to improve the quality of fruit of the cultivated species of the genus, and could represent relevant allelic forms. Our results corroborate previous reports about the specificity of phenolic profiles (Almaraz-Abarca et al. 2013).

\section{Antioxidant properties and correlation analysis}

All samples displayed important antioxidant properties. As scavengers of the free radical DPPH highlighted the fruits of $P$. hederifolia var. hederifolia (Table 2). All extracts showed higher scavenging activity than that reported by Chang et al. (2008) for the fruits of P. peruviana $\left(\mathrm{EC}_{50}\right.$ value around $\left.300 \mu \mathrm{g} / \mathrm{mL}\right)$. All extracts showed higher power to reduce Mo (VI) to Mo (V) than quercetin and epicatechin (Table 2), both considered as powerful antioxidants (Tapas et al. 2008). Leaves of $P$. subulata displayed until 44-fold higher values of TAC than any of two standards. All the foliar extracts showed higher iron reduction potential than the standards quercetin and 


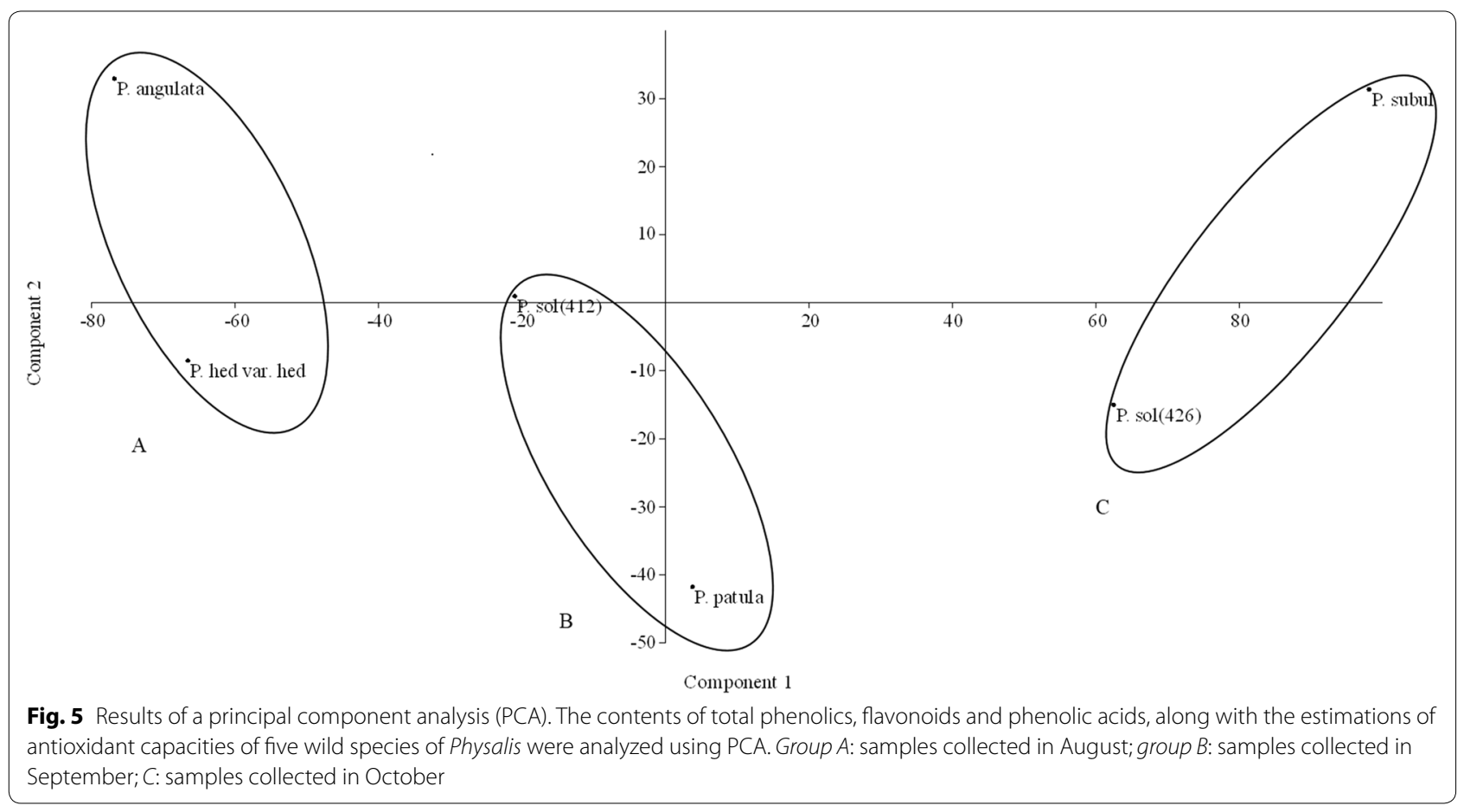

epicatechin (Table 2). However, the highest value, which was reached by the extract of calyces of $P$. solanacea (426) was lower than the value reported by Diaz et al. (2012) for the fruits of $P$. alkekengi ( $\mathrm{IC}_{50}=36.58 \mathrm{mg} / \mathrm{g}$ dry weight).

The variations found among the two samples of $P$. solanacea suggest that as the phenolic profiles were the same for both samples (Figs. 1, 2, 3), plant age caused variations in the concentrations of phenolics (Tables 2, 3), all which affected the antioxidant properties of tissues. These kind of effects have been reported for other plant species (Del Baño et al. 2003). In fruits, the accumulation of other antioxidants, like ascorbic acid, could affect the antioxidant properties. Synthesis of ascorbic acid has been reported in the fruits of $P$. peruviana (Rop et al. 2012) and may occur also in the species of Physalis here analyzed.

The low association between the antioxidant properties and the phenolic, flavonoid, and phenolic acid contents found in the present study agree with the reports of other authors (Morais et al. 2011; Barriada-Bernal et al. 2014), who suggested that the antioxidant potential of a given total extract depends not only on the amount of phenolic compounds present in it but also on the types of phenolics accumulated, their proportions, as well as the presence of compounds of different chemical nature.

\section{Principal component analysis}

The results of the PCA revealed a tendency of grouping based on the developmental stage (Fig. 5), group A included samples collected in August (P. hederifolia var. hederifolia and $P$. angulata), group B was formed by samples collected in September ( $P$. patula and $P$. solanacea 412 ), and group $C$ was formed by samples collected in October ( $P$. solanacea 426 and $P$. subulata). These results reveal the effect of time of collection and the associated developmental stage, on the phenolic, flavonoid, and phenolic acids contents and the antioxidant properties of different tissues of five wild species of Physalis. Systematic studies concerning the seasonal variation of phenolics of the species of Physalis are needed, as it has been done for some species of Betula (Raal et al. 2015), and concerning the developmental variation, as it has been carried out for Rosmarinus officinalis (Del Baño et al. 2003). Those studies would contribute to identify the best collecting time and developmental stage to obtain the highest concentration of some phenolic compounds and the environmental conditions in which they are produced.

\section{Conclusions}

The wild analyzed species of Physalis synthesize important amounts of diverse phenolic compounds. The phenolic profiles of leaves, fruits, and calyces were species-specific; this reveals phenolic patterns as significant specific chemomarkers in the genus. The dominant phenolic compounds accumulated in leaves and calyces were 3-O-glycoside derivatives of kaempferol, and the dominant ones in fruits were phenolic acids; all these compounds are recognized for their important activities 
as antioxidants. Because of their phenolic compositions, $P$. angulata, $P$. patula, $P$. hederifolia var. hederifolia, $P$. solanacea, and P. subulata may be considered as relevant potential sources of natural antioxidants to be used in the food and pharmaceutical industries. The present phenolic fingerprinting contributes to generate a better knowledge for using all the potential of these wild species of plants. The chemical variability of wild species of Physalis offers the opportunity for domesticating and developing new cultivars with enhanced accumulation of phenolics having positive effects on human health. The results inform about the importance of consuming these plant species and support the use of calyces and leaves in traditional medicine. The not always high correlation between phenolic or flavonoid contents and antioxidant activities suggests the relevance of the phenolic profiles, besides the contents of phenolics, in determining these activities.

\section{Abbreviations}

AAE: ascorbic acid equivalents; CE: $p$-coumaric acid equivalents; DAD: diode array detector; DPPH: 2,2-diphenyl-1-picrylhydrazyl; dt: dry tissue; $\mathrm{EC}_{50}$ : efficient concentration at $50 \%$; GAE: gallic acid equivalents; HPLC: high performance liquid chromatography; $I_{50}$ : half maximal inhibitory concentration NE: naringenin equivalents; PCA: principal component analysis; $\mathrm{PC}$ : principal component 1; PC2: principal component 2; QiE: quercitrin equivalents; TAC: total antioxidant capacity; UV: ultraviolet.

\section{Authors' contributions}

NAA conceived and designed the study. JRMM made collections of plant material and carried out the antioxidant capacity evaluations. LSGV and JNUS performed the HPLC-DAD analysis. NAA, LSGV, and JNUS analyzed and interpreted the data. MSGE and YHA conducted the botanical identification of the plants and made a critical revision, providing important intellectual content. All authors read and approved the final manuscript.

\section{Authors' information}

JRMM: Master in Science at National Polytechnic Institute (CIIDIR Durango IPN), his area of expertise is in Food Biotechnology. NAA: Dr., researcher at CIIDIR Durango IPN, her area of expertise is in Secondary Metabolism. MSGE: Dr., researcher at CIIDIR Durango IPN, she is Associate Editor of Acta Botanica Mexicana, her area of expertise is in Plant Systematics and Ecology. JNUS: Master in Science, researcher at CIIDIR Durango IPN, his research has been focused on Plant Production under Protected Environment. LSGV: Dr., researcher at CIIDIR Durango IPN, her area of expertise is on Environmental Analytical Chemistry. YHA: Dr., researcher at CIIDIR Durango IPN, her area of expertise is in Plant Systematics and Ecology.

\section{Acknowledgements}

The authors thank the Comisión de Operación y Fomento a las Actividades Académicas, Instituto Politécnico Nacional for the stimuli for research, and to Consejo Nacional de Ciencia y Tecnología for the grant (265393) to one of the authors.

\section{Compliance with ethical guidelines}

\section{Competing interests}

The authors declare that they have no competing interests.

Received: 16 February 2015 Accepted: 11 August 2015

Published online: 18 September 2015

\section{References}

Almaraz-Abarca N, González-Elizondo MS, Campos MG, Ávila-Sevilla ZE, Delgado-Alvarado EA, Ávila-Reyes JA (2013) Variability of the foliar phenol profiles of the Agave victoriae-reginae complex (Agavaceae). Bot Sci 91:295-306

Ames BM, Shigena MK, Hagen TM (1993) Oxidants, antioxidants and the degenerative diseases of aging. Proc Natl Acad Sci USA 90:7915-7922

Barriada-Bernal LG, Almaraz-Abarca N, Delgado-Alvarado EA, GallardoVelázquez T, Ávila-Reyes JA, Torrres-Morán MI, González-Elizondo MS, Herrera-Arrieta Y (2014) Flavonoid composition and antioxidant capacity of the edible flowers of Agave durangensis (Agavaceae). CyTA J Food 12:105-114

Campos MG, Markham KR (2007) Structure information from HPLC and on-line measured absorption spectra-flavone, flavonols and phenolic acids. Coimbra University Press, Coimbra

Chang JC, Lin CC, Wu SJ, Lin DL, Wang SS, Miaw CL, Ng LT (2008) Antioxidative and hepatoprotective effects of Physalis peruviana extract against acetaminophen-induced liver injury in rats. Pharm Biol 46:724-731

D'Arcy WG (1991) The Solanaceae since 1976, with a review of its biogeography. In: Hawkes JG, Lester M, Nee RN, Estrada N (eds) Solanaceae III: taxonomy, chemistry, and evolution. Royal Botanic Gardens, London

Del Baño MJ, Lorente J, Castillo J, Benavente-García O, del Río JA, Ortuño A, Quirin KW, Gerard D (2003) Phenolic diterpenes, flavones, and rosmarinic acid distribution during the development of leaves, flowers, stems and roots of Rosmarinus officinalis. Antioxidant activity. J Agric Food Chem 51:4247-4253

Diaz P, Jeong SC, Lee S, Khoo C, Koyyalamudi SR (2012) Antioxidant and antiinflammatory activities of selected medicinal plants and fungi containing phenolic and flavonoid compounds. Chin Med J 7:26

Dobre I, Dâdei G, Patrascu L, Elisei AM, Segal R (2010) The antioxidant activity of selected Romanian honeys. AUDJG Food Technol 34:67-73

Eick E (2008) Solanaceae and Convolvulaceae: Secondary metabolites. Biosynthesis, chemotaxonomy, biological and economic significance. Springer, Heidelberg

Emerenciano VP, Militão JS, Campos CC, Romoff P, Kaplan MA, Zambon M, Brant AJ (2001) Flavonoids as chemotaxonomic markers for Asteraceae. Biochem Syst Ecol 29:947-957

González-Mendoza D, Martínez-Ascencio D, Hau-Poox A, Mendez-Trujillo V, Grimaldo-Juárez O, Santiaguillo-Hernández J, Cervantes-Díaz L, AvilésMarin S (2011) Phenolic compounds and physiochemical analysis of Physalis ixocarpa genotypes. Sci Res Essays 6:3808-3814

Hernández J, Yáñez S (2009) Aprovechamiento tradicional de las especies de Physalis en México. R Geo Agric 43:81-86

Ismail N, Alam M (2001) A novel cytotoxic flavonoid glycoside from Physalis angulata. Fitoterapia 72:676-679

Kouloura E, Genta-Jouve G, Pergola C, Krauth V, Litaudon M, Benaki D, Wertz O, Michel S, Mikros E, Skaltsounis L, Halabalaki M (2014) Dereplication and metabolomics strategies for the discovery of bioactive natural products: the Acronychia example. Planta Med 80:SL3

Krishnaiah D, Sarbatly R, Nithyyanandam R (2011) A review of the antioxidant potential of medicinal plant species. Food Bioprod Process 89:217-233

Le K, Chiu F, Ng K (2007) Identification and quantification of antioxidants in Fructus lycii. Food Chem 105:353-363

Licodiedoff S, Koslowski LAD, Ribani RH (2013) Flavonols and antioxidant activity of Physalis peruviana L. fruits at two maturity stages. Acta Sci Technol 35:393-399

Mabry TJ, Markham KR, Thomas MB (1970) The systematic identification of flavonoids. Springer, New York

Maldonado E, Gutiérrez R, Pérez-Castorena AL, Martínez M (2012) Orizabolide, a new withanolide from Physalis orizabae. J Mex Chem Soc 56:128-130

Morais M, Moreira L, Feás X, Estevinho LM (2011) Honeybee-collected pollen from five Portuguese natural parks: palynological origin, phenolic content, antioxidant properties and antimicrobial activity. Food Chem Toxicol 49:1096-1101

Nurmi K, Ossipov V, Haukioja E, Pihlaja K (1996) Variation of total phenolic content and low-molecular-weight phenolics in foliage of the mountain birch trees (Betula pubescens ssp. tortuosa). J Chem Ecol 22:2033-2050

Pérez-Castorena AL, Hernández IZ, Martínez M, Maldonado E (2013) Chemical study of calyxes and roots of Physalis solanaceus. Rec Nat Prod $7: 230-233$ 
Prieto P, Pineda M, Aguilar M (1999) Spectrophotometric quantitation of antioxidant capacity through the formation of a phosphomolybdenum complex: specific application to the determination of Vitamin E. Anal Biochem 269:337-341

Raal A, Boikova T, Püssa T (2015) Content and dynamics of polyphenols in Betula spp. leaves naturally growing in Estonia. Rec Nat Prod 9:41-48

Robbins RJ (2003) Phenolic acids in foods: an overview of analytical methodology. J Agric Food Chem 51:2866-2887

Rockenbach II, Rodrigues E, Cataneo C, Gonzaga LV, Lima A, Mancini-Filho J, Fett R (2008) Phenolic acids and antioxidant activity of Physalis peruviana L. Alimentos e Nutrição 19:271-276

Rop O, Mlcek J, Jurikova T, Valsikova M (2012) Bioactive content and antioxidant capacity of cape gooseberry fruit. Cent Eur J Biol 7:672-679

Santiaguillo HJF, López RMA, Peña LA, Cuevas SC, Sahagún CJ (1994) Distribución, colecta y conservación de germoplasma de tomate de cáscara (Physalis ixocarpa Brot.). Rev Chapingo Ser Hortic 2:125-129

Siddhuraju P, Becker K (2003) Antioxidant properties of various solvent extracts of total phenolic constituents from three different agroclimatic origins of drumstick tree (Moringa oleifera Lam.) leaves. J Agric Food Chem 51:2144-2155

Tapas AR, Sakakar DM, Kakde RB (2008) Flavonoids as nutraceuticals: a review. Trop J Pharm Res 7:1089-1099

Veit M, Beckert C, Höhne C, Bauer K, Geiger H (1995) Iterspecific and intraspecific variation of phenolics in the genus Equisetum subgenus Equisetum. Phytochemistry 38:881-891
Wang SY, Lin HS (2000) Antioxidant activity in fruits and leaves of blackberry, raspberry, and strawberry varies with cultivar and developmental stage. J Agric Food Chem 48:140-146

Whitson M, Manos PS (2005) Untangling Physalis (Solanaceae) from the physaloids: a two-gene phylogeny of the Physalinae. Syst Bot 30:216-230

Wong RWK, Rabie ABM (2009) Grapefruit flavonoids: naringenin and naringinin. In: Keller RB (ed) Flavonoids. Biosynthesis, biological effects and dietary sources. Nova Science Publishers, New York, pp 141-180

Wu SJ, Chang SP, Lin DL, Wang SS, Hou FF, Ng LT (2009) Supercritical carbon dioxide extract of Physalis peruviana induced cell cycle arrest and apoptosis in human lung cancer H661 cells. Food Chem Toxicol 47:1132-1138

Zhang Q, Cui H (2005) Simultaneous determination of quercetin, kaempferol, and isorhamnetin in phytopharmaceuticals of Hippophae rhamnoides $\mathrm{L}$. by high-performance liquid chromatography with chemiluminescence detection. J Sep Sci 28:1171-1178

Zimmermann BF, Galensa R (2007) One for all-all for one: proof of authenticity and tracing of foods with flavonoids. Analysis of proanthocyanidins in barley and malt. Eur Food Res Technol 224:385-393

\section{Submit your manuscript to a SpringerOpen ${ }^{\odot}$ journal and benefit from:}

- Convenient online submission

- Rigorous peer review

- Immediate publication on acceptance

- Open access: articles freely available online

- High visibility within the field

- Retaining the copyright to your article

Submit your next manuscript at $>$ springeropen.com 